\title{
Clarice, CARolina E A ALEMANHA: REVERBERAÇÕES DA LITERATURA BRASILEIRA TRADUZIDA
}

\section{João Azenha Junior*}

Resumo: Este artigo tem por objetivo retraçar criticamente o percurso da orientação de duas dissertações de mestrado envolvendo a recepção de literatura brasileira traduzida na Alemanha. Ênfase é dada à construção de um aporte teórico afinado com os pressupostos das teorias sistêmicas da tradução, bem como à definição de um método voltado ao objetivo de "situar" os textos de trabalho em estudos de caso. Os resultados revelam tendências críticas que deixam entrever o esforço de articulistas alemães para acomodarem a recepção de tais obras no sistema literário alemão.

Palavras-chave: Literatura brasileira traduzida. Clarice Lispector. Carolina Maria de Jesus.

Tudo acaba, mas o que te escrevo continua.[...] O melhor está nas entrelinhas. (LISPECTOR, 2015 [1973], p. 92)

A voz dos pobres não tem poesia. [...] Eu sonhava ser um anjo e procurava as estrelas para contemplá-las e conversar com elas.

(JESUS, 1963, p. 123, 107)

\section{INTRODUÇÃO}

rabalhos de grau envolvendo estudos comparativos e contrastivos entre originais e traduções têm sido, ao longo dos anos, objeto de predileção de pesquisadores. Provas disso estão não apenas em numerosos docu- 
mentos que alavancaram o pensamento sobre tradução no curso de sua historiografia, mas também em registros de trabalhos de grau defendidos no campo dos Estudos da Tradução em diversas instituições.

No que respeita à literatura brasileira traduzida, querer saber como seria uma determinada obra de Machado de Assis em inglês ou espanhol, de Jorge Amado em russo ou chinês, entre tantos outros exemplos, parece continuar sendo alvo da curiosidade de pesquisadores, conforme demonstra a experiência de avaliar anteprojetos propostos por estudantes para ingresso em cursos de pós-graduação em Estudos da Tradução, seja no nível de mestrado, seja no de doutorado.

A despeito da validade de tais propostas, desenvolvidas metodologicamente mais no âmbito da linguística contrastiva e tendo por foco fenômenos específicos da linguagem - a comparação da tradução de termos culturalmente marcados, por exemplo, de partículas modalizadoras, de fraseologismos, entre outros -, cujo desenvolvimento tem prestado, ao longo do tempo, uma excelente contribuição para a descrição contrastiva de fenômenos específicos para um par de línguas, pesquisas realizadas no campo disciplinar dos Estudos da Tradução propriamente dito não podem passar ao largo das evoluções desses estudos verificada nas últimas cinco décadas. Não seria possivel ignorar temas e conquistas que envolvem a alternância entre perspectivas marcadas por abordagens universalistas, de um lado, e relativistas, de outro (CRUZ, 2012, p. 207), a ancoragem dos textos numa situação de comunicação emoldurada por fenômenos culturais próprios, a mirada prospectiva, voltada ao receptor e preconizada pelas teorias funcionais e descritivas, a ingerência de agentes na configuração final e no encaminhamento ao público e à crítica do texto traduzido, as instâncias manipuladoras que dirigem a recepção de obras, e por último, mas não menos importante, a escrita própria do sujeito-tradutor, que singulariza o resultado do seu trabalho e promove (ou não) sua visibilidade.

Assim, o lugar de trabalhos de natureza comparatista e contrastiva, no interior dos Estudos da Tradução, embora não tenham perdido sua validade e continuem a seduzir não apenas jovens pesquisadores, mas também a crítica especializada, passou a carecer, por força da evolução do campo disciplinar, de uma revisão de parâmetros capazes de amparar de forma mais robusta uma análise um pouco mais afinada com esses novos pressupostos.

Dessa revisão faz parte, primeiramente, a necessidade do estabelecimento de um "pano de fundo", de um cenário minimamente traçado das condições de produção do texto original e do texto traduzido, a partir do qual se possam aventar hipóteses para as escolhas de tradução e sobre o qual se possam, eventualmente, projetar resultados. O desenho desse cenário, nada fácil de ser traçado, associado aos limites de tempo cada vez mais exíguos para a conclusão de trabalhos de grau, desdobrou, por assim dizer, em pelo menos dois momentos os esforços de pesquisadores interessados em confrontar originais e suas traduções: acompanhando orientações metodológicas oriundas das teorias funcionais e sistêmicas, bem como da chamada Escola da Manipulação, ao tratamento contrastivo do "miolo" do livro se antepõem agora pesquisas de natureza exploratória e preparatória, descritivas, que visem, conforme se pontuou anteriormente, ao mapeamento das condições de produção do original, de um lado, e das condições de recepção, de outro. Tais pesquisas não apenas atendem às demandas dessas vertentes teóricas dos Estudos da Tradução, mas também 
buscam restabelecer, ainda que minimante, um contínuo entre obra e seu entorno, entre o texto e o mundo.

Como orientador, mas também como professor para teorias de tradução, continuo a apoiar pesquisas de natureza comparatista, desde que - a fim de fazerem jus aos avanços desses estudos - sejam desdobradas em etapas que, juntas, chegam a englobar dois niveis de formação: o mestrado e o doutorado. Nesse sentido, anteprojetos que me chegam às mãos para serem cumpridos no prazo do mestrado acabam utilizando toda essa etapa de formação para uma pesquisa preparatória, focalizada no entorno das obras, deixando para o nível de doutorado a continuidade da análise comparatista, se for esse o caso. Reside aí a primeira dificuldade para a orientação de tais trabalhos: convencer os estudantes a inverterem a perspectiva de análise - do entorno dos textos para dentro deles (e não o contrário) - e, como consequência disso, desdobrarem seus projetos, entendendo seus textos de trabalho não como exemplares desvinculados de um jogo de forças que envolve vários atores, mas sim como resultado de um processo complexo, no qual a figura de quem compara, longe de ser isenta, está totalmente comprometida com a análise e seus resultados.

Para este breve estudo, escolhi duas dissertações de mestrado, recentemente defendidas, que se concentraram no contexto e nas vertentes de recepção, na Alemanha, de obras das escritoras Clarice Lispector e Carolina Maria de Jesus. Os dois trabalhos - Castro (2013) e Nascimento (2016) - tiveram por objetivo mapear as condições de recepção, na Alemanha, de obras das duas escritoras por meio do estudo de resenhas críticas das obras traduzidas, publicadas em jornais de média e grande circulação, para daí derivarem eixos ou tendências críticas empregados pelos articulistas na tentativa de acomodarem as obras traduzidas no sistema literário alemão. Tais eixos revelaram aspectos da "função preparatória" dos comentadores (CASTRO, 2013, p. 42) nessa tentativa de acomodação, para o que eles se valem de redes associativas que dialogam tanto com a tradição literária ocidental quanto com a história e com outros sistemas sígnicos, em especial o cinema.

Esses mesmo eixos revelaram, ainda, o embate entre visões e imagens pré-concebidas da literatura e da cultura brasileiras, sedimentadas ao longo do tempo pela tradução de outros autores, e as novas perspectivas trazidas pela tradução de obras dessas duas escritoras. O resultado é o desenho de um cenário de recepção que reata, por assim dizer, os textos com dados de seu entorno ao fornecerem informações que, de alguma forma, colocam nas mãos do pesquisador dados que lhe permitem arriscar, com um grau um pouco maior de objetividade, possiveis explicações para opções de tradução mais pontuais.

Este estudo está assim estruturado: na sequência, faço um breve apanhado da moldura teórica que justifica e ampara essas pesquisas preparatórias, seguido de uma descrição dos caminhos (e descaminhos) da composição do método, para então apresentar uma sintese dos resultados e suas possiveis consequências para pesquisas posteriores.

\section{O PASSADO REVISITADO E A ANTECIPAÇÃo DO FUTURO}

Passado, presente e futuro são categorias que o exercício de tradução coloca por terra, sobretudo quando se adota para isso uma atitude sintonizada com as verten- 
tes funcional, cultural e descritiva dos Estudos da Tradução. A realização agora da tradução de um texto gerado num momento passado com os olhos voltados também para o cenário (futuro) de recepção define um fluxo contínuo entre esses três momentos, que é administrado por um sujeito a partir de objetivos primários e secundários e sob a influência de agentes que monitoram o processo de tradução.

Não se trata de uma posição confortável, por certo, mas talvez ela resuma o cerne da atividade-fim dos Estudos da Tradução, assim entendidos:

A tradução pura e simples de "Translation Studies" por "estudos da tradução" talvez deixe à margem o que de singular o sintagma inglês designa. A expressão em português é genérica e pode valer para todo e qualquer estudo relacionado à área de tradução. Já a expressão inglesa aponta para uma abordagem específica, que implicou uma completa mudança de paradigmas na investigação da tradução. Tal mudança se deu nos anos de 1970, e os novos paradigmas ganharam força na década seguinte, força que ainda se mantém até ofinal do século XX, pelo menos (CRUZ, 2007, p. 21).

Dessa reorientação fazem parte os chamados Estudos Descritivos da Tradução (EDT), uma das designações dessa nova vertente: “[...] os EDT correspondem a uma abordagem descritiva, empírica, interdisciplinar, orientada para o alvo, uma abordagem ao estudo de tradução, que focaliza especialmente seu papel na história cultural" (ROSA, 2010, p. 94, minha tradução).

Os EDT, portanto, preocupam-se em estudar as traduções tal como elas são, tal como já existem, bem como o contexto e a ingerência de fatores que as condicionaram. Nesse sentido, representam "uma mudança de paradigma no tratamento da tradução literária e o intercâmbio constante entre pressupostos teóricos e os estudos de caso" (CRUZ, 2007, p. 24).

O ponto de partida, então, para a ancoragem de trabalhos como os tratados neste estudo, tem por base a orientação e a convicção de pesquisadores de várias tendências e formações, que defendem

[...] uma visão da literatura como um sistema dinâmico e complexo; a convicção de que deve haver uma interação permanente entre modelos teóricos $e$ estudos de caso; uma abordagem da tradução literária de caráter descritivo e voltada para o texto-meta, além de funcional e sistêmica; e um interesse nas normas e coerções que governam a produção e a recepção de traduções, na relação entre a tradução e outros tipos de reescritura e no lugar e função da literatura traduzida tanto num determinado sistema literário quanto na interação entre literaturas (HERMANS, 1985, p. 10-11 apud MARTINS, 2010, p. 61, tradução de Márcia Martins).

Assim definida, essa vertente de estudos nos faz pensar em movimentos paralelos entre a Linguística, os Estudos Literários e os Estudos da Tradução, que emigram de modelos estáticos para uma abordagem dinâmica e que relacionam a linguagem com sua função sociocultural: a abrangência do olhar da palavra isolada para a frase, para o texto e para o contexto representa uma linha evolutiva que não pode ser ignorada e nem contestada, por mais ingênua que seja a visão que se tenha sobre língua, literatura ou tradução. 
Mesmo assim, a experiência ensina que, no exercício da tradução em contextos institucionais - na sala de aula, na pesquisa ou no ambiente empresarial -, a interiorização de preceitos teóricos, por assim dizer, não é imediata: via de regra, há um hiato entre o que se aprende com a teoria e o que se aplica no exercício da tradução, no trabalho ou na pesquisa.

Desse modo, do ponto de vista da operacionalização de conceitos em trabalhos de grau, não é difícil entender que, para se estudar um texto traduzido no interior da perspectiva brevemente descrita anteriormente, é preciso restabelecer um contínuo que reúna texto e mundo. A questão é saber como fazer isso e seguir essa orientação de forma coerente ao longo da realização do projeto: se, de um lado, podemos entender a literatura traduzida como parte de um polissistema dinâmico, em que obras, traduzidas ou não, se encontram num fluxo e numa competição constantes, de outro, precisamos "fixar" um ponto em meio a essa movimentação, a fim de viabilizarmos um estudo de caso.

As considerações dos parágrafos precedentes apontam, então, para a importância do método, para uma linha de procedimento que busque aliar, de forma coerente, os objetivos do trabalho com a ancoragem teórica que lhe serve de base.

Na leitura que faz do texto seminal de Toury (1995), Munday (2008) resume assim a metodologia trifásica proposta pelo teórico israelense:

(1) situar o texto e estudá-lo em função de sua importância e aceitabilidade;

(2) comparar o texto fonte e o texto-alvo em busca de desvios (shifts), identificando relações entre "pares acoplados" de segmentos do texto-fonte e do texto-meta; e (3) ensaiar generalizações, reconstruindo o processo de tradução para esse par de texto-fonte e texto-meta (MUNDAY, 2008, p. 111).

As três fases englobam etapas que, a rigor, teriam de ser cumpridas numa pesquisa de cunho contrastivo, a fim de que ficasse justificado o seu enquadramento na vertente descritiva. Atenho-me aqui à primeira etapa, que é, na verdade, aquela que pressupõe um trabalho de mapeamento bastante complexo e que, de fato, prepara o terreno para as etapas seguintes. Comentar as etapas dois e três, que remetem a conceitos controversos como a invariância e a equivalência e que receberam fortes críticas de comentadores como Gentzler (1993) e Hermans (1999), nos levaria para longe do foco deste estudo.

Ressalto, em princípio, a direção da pesquisa - top down e não bottom up que, por si só, inverte um parâmetro consensualmente aceito e adotado para pesquisas de cunho contrastivo e comparatista. Em outras palavras, não se procede de texto (original) para texto (traduzido), mas sim se fixa o olhar no que está fora dos dois. Esse procedimento, que Toury (1995) divide mutatis mutandis com Lambert e Van Gorp (2006 [1985]), mas também com Nord (2016 [1989]), pressupõe a capacidade, por parte do pesquisador, de administrar uma interação constante entre teoria e prática e de rejustar seu perfil - e os contornos de sua pesquisa - para o trabalho de campo, a fim de cumprir os requisitos de mapeamento que atribuem ao trabalho, ao menos num primeiro momento, o caráter de pesquisa descritiva.

Embora o procedimento vise identificar condicionantes e não exclua, de partida, o trabalho com o texto em si, o objetivo aqui é o de aventar hipóteses sobre leis - ou, para falar com Toury (1995, p. 53 ss.) - "normas" que 
governa(ra)m as traduções. Para tanto, cumpre primeiramente definir um objetivo, uma meta, uma função a ser desempenhada pelo texto de trabalho num horizonte de recepção determinado. Ganha ênfase, então, a consideração de fatores que, na abordagem imanente de um texto literário, ficam à sombra, relegados à condição de "segredos muito bem guardados", conforme reza o título do artigo de Frank (1998). Segredos que começam a vir à luz quando se examinam as instâncias que fazem a mediação entre o texto traduzido e o universo de receptores.

São esses agentes, que Lefevere (1992, p. 14 ss.) classifica como leitores profissionais ou reescritores (tradutores, comentaristas, criticos, entre outros) e não profissionais (os leitores em geral), que literalmente "manipulam" o processo de inserção de um texto traduzido num dado sistema literário:

É talvez devido a esse poder de propagação que as reescrituras, em todas as suas formas, ocupam posição dominante entre os "fatos concretos" que movimentam o processo de aceitação ou rejeição, canonização ou não canonização de obras literárias. E é desse modo que o autor [Lefevere] enfatiza a importância das reescrituras como "motor" da evolução literária (CRUZ, 2007, p. 39).

Vemos, então, que para "situarmos" um texto traduzido, nos termos de Toury (1995), os paratextos nele inseridos (peritextos) e também veiculados sobre eles em suportes midiáticos (epitextos) - para usarmos uma classificação de Genette (2009, p. 9 ss.) - constituem, juntamente com o texto em si, um conjunto de informações que podem ser entendidas como elos para o restabelecimento do já mencionado contínuo entre o livro e o mundo:

Estritamente, a crítica ou a apresentação das obras dadas pelas editoras nos paratextos de suas edições não seriam reescrituras, da mesma forma que o são a tradução ou o resumo. Entretanto, os textos dos paratextos coincidem com a ideia de reescritura no que também propõem e propagam imagens de um autor e de uma obra. Creio ser possível assim estender o conceito proposto por Lefevere, de modo a compreender também as interpretações divulgadas sobre uma obra como reescrituras dessa obra (CRUZ, 2007, p. 39).

A consideração, então, desse conjunto formado por obra (traduzida) e paratextos de e sobre ela reata laços, revela bastidores, apela a um (possivel) horizonte de expectativas do leitor (CASTRO, 2013, p. 35), direciona leituras e contribui para a configuração de um nicho que vai acolher a obra traduzida no sistema literário receptor. O estudo desse conjunto pode ser entendido, pois, como o estudo do terreno preparado por esses comentadores-reescritores e de seu compromisso com a comunidade interpretativa de que fazem parte.

\section{A CONSTRUÇÃo DO MÉtodo: ECLETISMO E INTERSECÇÕES}

Os dois trabalhos aqui comentados concentraram-se nessa primeira etapa da metodologia proposta por Toury (1995). O foco de ambas as pesquisas foi direcionado para a tentativa de estabelecer o contínuo entre o livro traduzido e seu ambiente de recepção e recaiu, conforme já apontado, na recolha e no estudo 
dos paratextos de seus primeiros reescritores profissionais: resenhistas, em sua maioria estudiosos de literatura.

Para o trabalho de Castro (2013), foram estudadas dez traduções de diferentes obras da escritora Clarice Lispector, publicadas entre 1964 e 1996, cinco delas com reedições, e dessas cinco, duas obras com duas reedições. A complementação desse conjunto contou com a inclusão de 25 textos veiculados em dez jornais, nove resenhas literárias, 19 releases editoriais e três outros textos de caráter mais geral, não relacionados a uma obra específica, mas sim à obra de Lispector como um todo. O corpus principal da pesquisa, subtraídas as traduções propriamente ditas, compôs-se, então, de um total de 56 textos.

Para a pesquisa de Nascimento (2016), foram estudadas sete edições de traduções para a obra Quarto de despejo, de Carolina Maria de Jesus, comentadas em 11 resenhas escritas entre 1962 e 1996, e veiculadas em vários jornais alemães de média e grande circulação.

A primeira dificuldade enfrentada pelos pesquisadores foi a recolha dos textos que compuseram os corpora: não parece ter sido prática das editoras alemãs, ao menos no período anterior ao início deste século, preservar versões intermediárias das traduções, nem tampouco o material de divulgação, circulação e crítica das traduções por elas publicadas. As visitas virtuais e presenciais dos dois pesquisadores a editoras e bibliotecas alemãs, além de tomarem um tempo considerável da pesquisa, renderam mais negativas do que resultados concretos, o que quase inviabilizou os dois projetos.

Em compensação, foi decisiva a atuação de Klaus Küpper, pesquisador aficionado pela literatura produzida nas Américas do Sul e no Caribe, que desde 1982 trabalha sistematicamente, com a ajuda de um grupo pequeno de colaboradores, na construção de um arquivo sobre a tradução, ao alemão, da literatura produzida nas Américas do Sul e Central, bem como do material escrito sobre elas e publicado na mídia alemã ${ }^{1}$. Sem a prestimosa colaboração de Küpper, que de bom grado se dispôs a assessorar os dois pesquisadores, o material descrito não poderia ter sido reunido.

O passo a passo das pesquisas seguiu caminhos parecidos. No caso de Castro (2013, p. 78) as obras traduzidas foram primeiramente organizadas cronologicamente. Cada obra traduzida foi acompanhada, então, das publicações a ela referentes, ao que se seguiu a leitura sistemática de cada um dos conjuntos, acompanhada de anotações primeiramente assistemáticas, com vistas a "depreender de cada um destes momentos de recepção o juízo que se fez sobre a escritora e sua obra". Na sequência, todo o material foi reorganizado, dessa vez por título (incluindo as reedições), a fim de se obter uma visão de conjunto de cada obra e de sua repercussão. Os novos conjuntos foram então relidos e as primeiras notas, apuradas, com o intuito de se identificarem sobreposições e reiterações que permitissem identificar tendências críticas. Trechos das resenhas foram então selecionados, traduzidos e apresentados num capítulo do trabalho em formato bilingue alemão/português.

Ao final dessas etapas, chegou-se à definição de cinco vertentes principais para a recepção da obra de Lispector ao longo das mais de três décadas focalizadas pelo estudo: 1. o engavetamento feminista; 2. a associação a autores canônicos

1 Para maiores informações sobre o arquivo de Küpper, consulte o site <www.lateinamerikaarchiv.de>. 
(não só alemães); 3. o caráter inovador; 4. o desvio do regionalismo e da denúncia social; e 5. a linguagem hermética e o viés filosófico (CASTRO, 2013, p. 78).

Para a pesquisa de Nascimento (2016), a Linguística de Corpus foi empregada como ferramenta para o tratamento das 11 resenhas. Após a preparação dos textos, que envolveu a conversão de imagens em textos, bem como sua revisão ortográfica, foram elaboradas listas de palavras com o auxílio da ferramenta AntConc®. Em seguida, um corpus de referência foi construído para a extração de palavras-chave, tanto para o conjunto das 11 resenhas quanto para cada resenha isoladamente, neste último caso usando o corpus mesmo das resenhas como corpus de referência.

A partir daí, foram determinados dois eixos temáticos no interior dos quais os comentadores alemães procuraram acomodar (e direcionar) a recepção da obra de Carolina Maira de Jesus: o eixo político-social e o literário (NASCIMENTO, 2016, p. 46). O passo seguinte foi reclassificar as resenhas com a ajuda das palavras-chave de cada uma e selecionar excertos de cada resenha, que - a exemplo do trabalho de Castro (2013) - também foram traduzidos e apresentados em versão bilingue alemão/português. Como se tratava de aquilatar opiniões sobre as obras estudadas, de se identificar, em suma, o ponto de vista do articulista sobre a(s) obra(s), nos dois trabalhos foram estabelecidos critérios para a tradução dos excertos, norteados pela literalidade, sem aclimatações ou acomodações, o que acabou resultando em versões às vezes pouco fluentes, mas inteligiveis.

\section{OS RESUlTADOS: CONVERGÊNCIAS, DIVERGÊNCIAS E ASSOCIAÇÕES}

As duas pesquisas enfocaram períodos quase coincidentes de recepção das obras das duas escritoras: no caso de Clarice, de 1964 a 1996 e, para Carolina, de 1962 a 1996. Embora se trate de estudos de caso, uma primeira hipótese a ser aventada aqui é a de que essas três décadas podem indicar uma disposição auspiciosa do sistema literário alemão para a recepção de literatura brasileira com a consequente revisão, disso decorrente, do olhar alemão sobre a literatura produzida entre nós, conforme veremos adiante quando falarmos das reverberações das obras.

Outra constatação que resulta da recolha dos corpora diz respeito tanto ao número de obras e de reedições de obras, como no caso de Clarice, quanto ao número de edições da obra de Carolina. Do vínculo dessas edições (e reedições) de obras com diferentes momentos e propostas editoriais ao longo de cerca de três décadas resulta, para um eventual trabalho de cunho comparatista, relacionar rigorosamente a edição (ou reedição) estudada com o respectivo original que lhe serviu de base, bem como com todas as informações paratextuais que, junto com eles, compõem um conjunto complexo. Assim, quem desejar saber como Clarice ou Carolina "são" em alemão, não poderá escolher a esmo qualquer versão alemã para um livro, também qualquer, dessas duas escritoras: ao original $x$ deve corresponder a edição (ou reedição) $y$, acompanhada do estudo de seus paratextos. Afinal, desse conjunto singular, emergem vieses de leituras que diferem de outros conjuntos, também singulares, seja porque ancorados em outros momentos ou em outras propostas editoriais, seja porque construídos por um olhar que se concentra em elementos e sugestões diferentes. 
Nas duas pesquisas, chamam atenção as reverberações, aqui entendidas como redes associativas a que os articulistas recorrem na tentativa tanto de interpretarem as obras estrangeiras por eles focalizadas quanto para acomodá-las, de alguma forma, ao seu sistema literário. Essas tentativas de assimilação do Outro, do Diferente, percorrem caminhos que passam por associações a autores e obras da literatura ocidental, a gêneros literários, à história e a sistemas sígnicos diferentes, mais especificamente ao cinema.

Para as obras de Clarice Lispector, considerados os cinco eixos de tendências críticas mencionados anteriormente, parece prevalecer a impressão da escrita que intriga, que incomoda. O mergulho no ser, a introspecção. Assim, para além da superficie do estranhamento, a obra da escritora parece atingir seus leitores profissionais num ponto em que os faz perderem suas referências mais superficiais, ou mesmo pré-concebidas sobre a literatura brasileira conhecida até então.

Nesse sentido, pela escrita de Clarice não estar ancorada num estrato mais concreto de estranhamento, quer dizer, em dados e referentes de uma realidade estrangeira e estranha como no caso da literatura regionalista brasileira, por exemplo, mas sim num plano mais profundo, que desencadeia reflexão sobre a existência mesma do ser humano na sua relação consigo e com o mundo, os articulistas que comentam e resenham as obras da escritora publicadas em alemão buscam relacioná-la, preponderantemente, com a obra de outros escritores que para eles podem evocar reações análogas.

Vejamos a seguir a plêiade de autores e autoras da literatura ocidental com os quais as obras de Clarice são associadas ao longo do estudo de Castro (2013). Atenho-me aqui a uma enumeração pura e simples, já que o trabalho do pesquisador aprofunda, na medida do possivel, essas relações. Os números que se seguem aos nomes de autores e autoras referem-se às páginas do trabalho de Castro em que a referência pode ser encontrada. A sequência dos eixos de recepção não corresponde a momentos dispostos no tempo numa ordem cronológica, conforme nos informa Castro (2013, p. 79), mas sim a tendências críticas, às vezes concomitantes, com as quais a obra da escritora é alinhada.

Para o primeiro eixo - $\mathrm{O}$ engavetamento feminista -, surgem primeiramente na imprensa alemã reverberações da recepção francesa de Clarice iniciada na França na década de 1950 e associadas ao nome da escritora e crítica literária Hélène Cixous. Nesse mesmo eixo, Clarice e sua obra são associadas a Virginia Woolf, Ingeborg Bachmann e Julia Kristeva (82), mas também a Jorge Luis Borges, Gabriel García Marques e Julio Cortázar (83), neste último caso como uma das vozes da América Latina.

Para o segundo eixo, que Castro chama de "Weltliteratur [literatura universal]: Clarice canônica", os textos estudados tentam estabelecer paralelos entre obras de Clarice e obras de Virginia Woolf (96), Kafka, Rilke e Rimbaud (97), Heidegger e Dostoievski (99), James Joyce, novamente Virginia Woolf, William Faulkner e Jorge Luis Borges. Aqui, sob o ponto de vista de um cânone literário universal, Clarice é vista como um elo dessa linha evolutiva. No interior do mesmo paradigma, surgem associações com Katherine Mansfield (101), Paul Claudel (102), Samuel Beckett (103) e até com Johann Wolfgang von Goethe (106) e o Bildungsroman [romance de formação], nos comentários ao livro Uma aprendizagem ou o livro dos prazeres. 
O terceiro eixo - Clarice inovadora - revela reverberações da fortuna crítica brasileira sobre a autora na recepção alemã, quer dizer, surgem ecos, na crítica alemã, do que teóricos da literatura brasileira, em especial Antonio Candido (107), escreveram sobre a autora e sua obra. É interessante observar que, para os articulistas alemães interessados por literatura brasileira, não apenas a obra de escritores lhes era conhecida, mas também parte de sua fortuna crítica produzida no Brasil. Ainda no quesito do caráter inovador, a obra de Clarice é alinhada com a de Guimarães Rosa (112).

O quarto eixo estudado - O desvio do regionalismo e da denúncia social - nos traz considerações sobre Lispector que a afastam de uma tendência que se poderia chamar de "engajada", isto é, a obra da escritora é apresentada como voltada não para o entorno, mas para dentro do ser. Como contraponto de sua obra em relação à literatura brasileira produzida por autores e autoras contemporâneos, surge o nome de Raquel de Queiroz (113). Esse desvio em relação ao realismo sublinha o vínculo da escritora com a modernidade europeia (114), ao mesmo tempo que a distância de escritores como Jorge Amado, José Lins do Rego e Érico Veríssimo, cuja obra é vista pelos articulistas alemães como "o exagero em folclore e em literatura provincial" (115).

No quinto e último eixo - Linguagem hermética cingida por deslinde metafisico - talvez o mais importante para a caracterização da escritora, a obra clariciana é vista como "bruxaria em ação e força hipnótica" (124). Dostoievski (125) é novamente invocado, ao mesmo tempo que as obras de Clarice e sua significação e profundidade são associadas a outros universos sígnicos vindos da improvisação jazzística (132), mas também da música erudita - Bach, Vivaldi e Händel (132) -, além da pintura (132). Nesse mesmo domínio são arrolados os nomes de Roland Barthes (132), Kafka e A metamorfose (136-137), tudo isso na tentativa de dimensionar o impacto da obra de Lispector e, como já dito anteriormente, a perda de referências pré-formatadas, por assim dizer, sobre a literatura brasileira (145). Numa das resenhas comentadas no interior desse eixo, Clarice aparece ao lado de Platão (145).

Como vemos, o esforço dos comentadores em preparem os terrenos para os leitores não profissionais da obra de Clarice em alemão busca estabelecer um horizonte de referências que está além do que, provavelmente até então, seria de esperar da literatura brasileira traduzida. O estabelecimento dessas balizas de apoio para a recepção da obra da escritora naturalmente terá um impacto também sobre a própria imagem da literatura brasileira na Alemanha, conforme sugerem os títulos dos dois trabalhos aqui estudados. Retomarei esse ponto ao final deste estudo.

No trabalho de Nascimento (2016, p. 15), o mote que norteia o processo de recepção das várias edições de Quarto de despejo parece concentrar-se no impacto editorial que o livro e a própria Carolina Maria de Jesus provocaram no Brasil e nos mais de 40 países em que a obra foi publicada em tradução para 13 idiomas. A questão que intriga quase todos os articulistas alemães parece concentrar-se numa dúvida: a que, de fato, tal impacto poderia ser atribuído? Aos méritos literários da obra e à dimensão poética da escrita de Carolina, de um lado, ou aos efeitos de um relato cru, impactante, acerca de uma dura realidade urbana marcada por desigualdades sociais impressionantes, de outro? 
De certo, segundo Nascimento (2016, p. 17), contribuiu para a tradução da obra o fato de que

Na Alemanha, a tradução da obra [Quarto de Despejo] foi realizada em um momento em que outros diários de cunho político-social eram traduzidos, como os diários de Erwin Behrens (Diário de Moscou), de Thilo Koch (Diário de Washington) e de Josef Müller-Marein (Diário do Oeste), revelando certa tendência da época por obras literárias voltadas para esse viés de denúncia política e social.

Mesmo assim, as opiniões sobre Carolina e sua obra parecem oscilar entre a "poetisa do lixo" $(52,53,55)^{2}$ e o relato de denúncia, o documento. Essa dúvida e o pêndulo que oscila de um lado a outro nas diferentes resenhas colocam em foco a questão de saber até que ponto a literatura-denúncia, ainda que aqui e ali elaborada num nivel de poeticidade e expressividade impressionantes, é mesmo capaz de alterar concretamente uma dura realidade: o peso esmagador da vida de milhares de pessoas vivendo em condições sub-humanas nos barracos na extinta Favela do Canindé, na cidade de São Paulo $(60,92)$. Esse questionamento, que Nascimento (2016) detecta ao longo das três décadas de textos sobre a autora e o livro escritos na Alemanha, parece apontar para uma perplexidade quase inacreditável ao olhar alemão diante do livro. E se levarmos em conta o espelhamento criado pela relação com a própria vida da autora - Carolina partiu da miséria, conheceu a fama e terminou na miséria - a resposta a essa pergunta parece tender para o não, quer dizer, para a negativa de que mesmo a literatura na forma do relato, por mais próxima que esteja da realidade que ela tenta refletir e, assim, transformar em ficção, pode sensibilizar, sim, as pessoas para questões pungentes, mas pouco pode fazer para alterar a realidade que reflete.

À perplexidade mencionada, soma-se outro aspecto, tangenciado pelo trabalho de Nascimento (2016), mas não suficientemente desenvolvido por extrapolar o escopo da pesquisa empreendida. Trata-se aqui do aparente desconforto provocado nos articulistas pelo fato de essa escritora de sucesso, cuja obra transbordou para o mundo, ser, além de negra, catadora de lixo e favelada. Em várias resenhas, adjetivos como "negra", "de cor" e "favelada" são empregados para acompanhar o substantivo "escritora", em momentos em que essa associação seria absolutamente dispensável (93, 119, entre outros). O elemento "politicamente correto" não funcionou nesses casos e deixa entrever um estranhamento que, à época da redação das resenhas, ainda podia ser externado sem provocar fortes reações adversas.

Essa linha que costura a leitura das resenhas sobre Quarto de despejo e sua autora também é responsável por construir, de um lado e de outro desse pêndulo, que vai da dimensão literária da obra ao seu caráter de relato-denúncia, redes associativas que tentam explicar ao leitor alemão estratos e referências de uma realidade que não lhe são familiares. Tais redes visam dar sustentação às opiniões que Nascimento (2016, p. 51) procurou concentrar nos dois eixos determinados para a pesquisa: o político-social e o literário. Naturalmente, os eixos se sobrepõem em muitos momentos e devem ser vistos apenas como uma

\footnotetext{
2 Também aqui, os números entre parêntesis remetem às páginas do trabalho de Nascimento (2016) em que o assunto é tratado.
} 
tentativa de organizar as opiniões encontradas. Neste estudo, procurei sintetizar tais redes associativas ligando-as a: 1 . escritores e personalidades da política, 2. topônimos, 3. personagens de obras literárias conhecidas do público alemão, 4. filmes e 5. referências indiretas a autores e eventos. Também aqui me atenho a elencar tais referências, que são discutidas em pormenores na pesquisa que serviu de base a essas considerações.

Para o primeiro item, Carolina aparece associada à abolicionista e escritora estadunidense Harriet Beecher Stowe (53), mais especificamente à sua obra $A$ cabana do Pai Tomás, publicada em 1852. A referência desloca o foco da discussão à problemática do negro norte-americano que mutatis mutandis estabelece todo um referencial associado à escravidão, às guerras pela libertação da escravatura e também aos ódios gerados por esses embates em solo norte-americano, com repercussões até os dias de hoje. É também nesse sentido que se menciona a figura de Marian Anderson (63), cantora negra do cenário operístico norte-americano quando de sua visita ao Rio de Janeiro, cujo hotel em que se encontrava hospedada foi apedrejado. O racismo é aqui, então, o tema central da discussão. A ele se agrega a dimensão tanto da luta pela igualdade de direitos, como da insurreição e da dissidência em relação a um status quo, como na referência a Fidel Castro (70, 125), contraponto em relação a seu poderoso vizinho, os Estados Unidos da América, à época da redação das resenhas mergulhado na chamada guerra fria.

Para este primeiro item, mas agora com foco sobre a obra e a escrita de Carolina, aparecem os nomes de Bertolt Brecht $(61,69)$, mais especificamente sua peça teatral Mãe Coragem, bem como os poetas Ernst Stadler e Georg Heym (68), representantes da lírica expressionista alemã. Ao lado de Franz Kafka (70, $71,75)$, esses autores da literatura alemã são invocados para estabelecer um conjunto de referências que constitua um contraponto, um ponto de fuga na obra de Carolina para toda a dimensão de denúncia contida em seu livro-relato. Stefan Zweig (102) e, em especial, sua obra Brasil, pais do futuro, publicado em 1941, também surgem como mais uma associação importante, não sem um laivo de ironia sobre se o Brasil seria mesmo esse "país do futuro". Também o nome e o conjunto da obra de Danilo Dolci (1924-1997), que retrata a vida no sudoeste da Sicilia, fazem a ponte, aqui, para a tentativa dos comentadores de explicarem ao leitor alemão o conceito de "favela", não apenas no que respeita à dificuldade de tradução do termo ao alemão - vários articulistas preferem empregar o conceito "Elendsviertel" [bairro de miséria] -, mas também para gerar redes associativas que visem reconstruir, ao menos em parte, as condições sub-humanas da vida das pessoas que ali residem.

Assim, alguns topônimos são mencionados ao longo das resenhas para evocarem lugares "parecidos" com o que se imagina(va) ser uma favela, não sem também deixarem entrever a visão que os próprios articulistas alemães têm (ou tinham) dos lugares a que se referem. Ao lado da Sicília, mencionada na referência a Danilo Dolci, também a periferia da cidade de Milão é trazida à baila $(62,63)$ e o adjetivo "napolitana" é empregado para caracterizar a cidade do Rio de Janeiro (63). Alguns lugares da Itália, portanto, parecem surgir aqui como (anti-)referência à ordem, organização e condições dignas de vida ${ }^{3}$.

3 Tratei desse tema num texto em que discuto a repercussão, num texto da imprensa alemã, da solenidade fúnebre de despedida ao papa João Paulo II. Confira Azenha Junior (2008). 
Quanto às referências a personagens da literatura, chamam atenção as menções à personagem central da Mãe Coragem (61), de Brecht, e à "Cinderela Negra” (76), numa clara alusão ao conto dos Irmãos Grimm. Ambas as designações estão presentes nos títulos de duas resenhas e sua relação com a vida e obra de Carolina é conduzida, ainda que de forma breve, no sentido de apontar convergências e divergências entre essas histórias aparentemente tão distantes, mas que se entrecruzam de alguma forma. Um exercício de aproximação, portanto. A referência à personagem e obra Cândido, de Voltaire, também é evocada numa das resenhas para sublinhar a perplexidade do resenhista ao constatar que ainda possa haver alguém que desconheça a vida nas favelas brasileiras. Para ironizar esses "cândidos", o resenhista empresta a palavra a Jean-Paul Sartre, que teria dito sobre o Rio de Janeiro: “Copacabana é apenas a vitrine, a realidade está atrás delas, nas favelas” (67).

Com o mesmo intuito de caracterizar a ambientação do livro de Carolina, surgem alusões aos filmes Rocco e seus irmãos (63), dirigido por Luchino Visconti em 1960, e Orfeu Negro (105), rodado por Marcel Camus em 1958. São referências concretas, que desencadeiam redes associativas que apelam aos sentidos, já que são capazes de dar corpo, voz, cor e movimento a essa ambientação, cada filme à sua maneira.

Por fim, as referências indiretas à Rússia e à revolução de 1917, traduzidas no uso de atributos como "comunistas" (84) e "proletariado" (69), este último empregado no sentido de caracterizar a massa de pessoas relegadas ao esquecimento no interior da favela do Canindé. Nesse mesmo contexto que remete à Rússia do final do czarismo estão também as menções indiretas a Dostoievski, aqui menos no sentido a que o escritor foi relacionado nas resenhas sobre Clarice Lispector, e mais no que sua obra pode conter de denúncia e de apelo desencadeador de levantes sociais modificadores de uma realidade.

\section{Para finalizar: a Cena encaixada no esboço de um Cenário}

Este estudo perseguiu o objetivo de retraçar criticamente o percurso de orientação de duas dissertações de mestrado voltadas a mapear o contexto e o potencial de recepção, na Alemanha, de obras das escritoras Clarice Lispector e Carolina Maria de Jesus. Nos dois casos, tratava-se inicialmente de projetos voltados à análise contrastiva entre originais das obras das escritoras e suas versões alemãs. Contudo, a fim de ancorar os trabalhos no âmbito dos Estudos da Tradução e de fazer jus, assim, ao desenvolvimento de vertentes teóricas desses estudos, as duas dissertações tiveram seu curso inicial alterado e concentraram-se na primeira etapa do percurso metodológico proposto por Toury (1995), destinada a situar os textos traduzidos no sistema literário receptor.

Os resultados desse mapeamento, conforme apontado nos parágrafos precedentes delineiam os contornos de um cenário, no interior do qual as sucessivas edições das obras de Clarice e do livro de Carolina foram sendo lidas e resenhadas primeiramente por articulistas preocupados em preparar, a cada vez, o terreno para a sua recepção ao longo de três décadas.

Para tanto, o elemento estrangeiro, não familiar, contido nas obras dessas escritoras foi sendo paulatinamente aclimatado por diversas referências que buscavam relacionar as obras com outras obras e escritores da literatura oci- 
dental, com personagens de obras conhecidas, com fatos da história, mas também com lugares e filmes. No caso de Clarice, a escritora intrigante, de escrita voltada para dentro, forçou a revisão do que provavelmente seria de esperar de uma obra da literatura brasileira, seja o exotismo da vida nos trópicos, seja a denúncia social marcada provavelmente pela familiaridade de uma parcela do público alemão com o realismo das obras brasileiras de cunho regionalista. No caso de Carolina, a questão da denúncia social ganhou outra face: não o regionalismo, mas a denúncia urbana, corporificada pela desigualdade social nos grandes centros.

Embora se trate de universos de referências diferentes em ambos os casos, fato é que esses estudos exploratórios revelam estratos de percepção e, portanto, de recepção diferentes que, somando-se aos demais, já sedimentados ou em vias de sedimentação no sistema literário alemão, reajustam a imagem da literatura brasileira na Alemanha no curso do tempo e da história das culturas. Tais estratos, à parte sua capacidade de engendrarem muitas outras pesquisas sugeridas pelas redes associativas invocadas, confirmam que, através da tradução e de sua leitura e direcionamento por diferentes agentes, a noção que uma literatura faz de outra aos poucos vai se transformando, ganhando corpo e relevo para passar de uma forma inicial, aplainada e bidimensional, para outra, que comporta múltiplas perspectivas.

Esses nichos, dentro dos quais as obras traduzidas vão sendo acomodadas, ainda que deixem a desejar no que concerne ao estabelecimento de parâmetros mais objetivos a serem empregados numa eventual análise contrastiva entre originais e traduções, pelo menos determinam o que eu chamaria aqui de chaves de leitura, tendências de interpretação que se alternam de momento a momento ao longo do processo de aproximação das literaturas. Vencida, então, essa primeira etapa de mapeamento da recepção, as pesquisas de cunho contrastivo passam a ser empreendidas não mais num vácuo de relações, mas sim no interior de um cenário um pouco mais definido e, como consequência disso, num leque mais reduzido de possibilidades.

\title{
Clarice, Carolina and Germany: Reverberations of the translated Brazilian LITERATURE
}

\begin{abstract}
This article aims at critically retracing the course of the orientation of two master's dissertations involving the reception of Brazilian literature translated into German. Emphasis is given to the construction of a theoretical approach in tune with the assumptions of the systemic theories of translation, as well as to the definition of a method aimed at "situating" the working texts in case studies. The results show critical trends that reveal the efforts of German critics to accommodate the reception of such works in the German literary system.
\end{abstract}

Keywords: Translated Brazilian literature. Clarice Lispector. Carolina Maria de Jesus. 


\section{REFERÊNCIAS}

AZENHA JUNIOR, J. Text linguistics and translation: redefining the concept of "cultural mark". TradTerm, São Paulo, v. 14, p. 51-71, 2008.

CASTRO, T. A. B. de. Um outro olhar sobre a literatura brasileira: Clarice Lispector em tradução alemã. 2013. Dissertação (Mestrado em Letras)-Faculdade de Filosofia, Letras e Ciências Humanas, Universidade de São Paulo, São Paulo, 2013.

CRUZ, C. Metamorfoses de Kafka. São Paulo: AnnaBlume; Fapesp, 2007.

CRUZ, C. O trabalho do tradutor: em busca de uma teoria para a prática. 2012. Tese (Doutorado em Letras)-Faculdade de Filosofia, Letras e Ciências Humanas, Universidade de São Paulo, São Paulo, 2012.

FRANK, A. P. Schattenkultur and other well-kept-secrets: from historical Translation Studies to literary historiography. In: MUELLER-VOLLMER, K.; IRMSCHER, M. (Ed.). Translating literatures, translating cultures: new vistas and approaches in literary studies. Stanford: Stanford University Press, 1998.

GENETTE, G. Paratextos editoriais. Tradução Álvaro Faleiros. São Paulo: Ateliê, 2009.

GENTZLER, E. Contemporary translation theories. London; New York: Routledge, 1993.

HERMANS, T. Translation studies and a new paradigm. In: HERMANS, T. (Ed.). The manipulation of literature: studies in literary translation. London: Croom Helm, 1985. p. 7-15.

HERMANS, T. Translation in systems. Manchester: St Jerome, 1999.

JESUS, C. M. de Quarto de Despejo: diário de uma favelada. 9. ed. São Paulo: Livraria Francisco Alves, 1963. Edição Popular.

LAMBERT, J.-R.; VAN GORP, H. On describing translations. In: HERMANS, T. (Ed.). The manipulation of literature: studies in literary translation. London: Croom Helm, 1985. p. 42-53. Reimpresso em DELABASTITA, D.; D'HULST, L.; MEYLAERTS, R. (Ed.). Functional approaches to culture and translation: selected papers by José Lambert. Amsterdam; Philadelphia: John Benjamins, 2006. p. 37-47.

LEFEVERE, A. Translation, rewriting and the manipulation of literary fame. London; New York: Routledge, 1992.

LISPECTOR, C. Água Viva. Rio de Janeiro: Rocco Digital, 2015. 1. ed. 1973. Recurso eletrônico.

MARTINS, M. A. P. As contribuições de André Lefevere e Lawrence Venuti para a teoria da tradução. Cadernos de Letras, Rio de Janeiro, n. 27, p. 59-72, 2010. Disponivel em: <http://www.letras.ufrj.br/anglo_germanicas/cadernos/numeros/122010/textos/cl301220100marcia.pdf>. Acesso em: 25 out. 2017.

MUNDAY, J. Introducing translation studies. Theories and applications. 2. ed. London; New York: Routledge, 2008.

NASCIMENTO, R. A. dos S. Do exotismo à denúncia social: sobre a recepção de Quarto de despejo, de Carolina Maria de Jesus, na Alemanha. 2016. Disserta- 
ção (Mestrado em Letras)-Faculdade de Filosofia, Letras e Ciências Humanas, Universidade de São Paulo, São Paulo, 2016.

NORD, C. Lealdade em vez de fidelidade: proposta de uma tipologia funcional da tradução. Cadernos de Tradução. Tradução de Cristiane Krause Kilian. Revisão de Luciane Leipnitz e Renan Lassarin, Porto Alegre, p. 9-24, 2016. Traduzido a partir do texto Loyalitãt statt Treue: Vorschläge zu einer funktionalen Übersetzungstypologie, Lebende Sprachen, v. 34, p. 100-105, 1989.

ROSA, A. A. Descriptive Translation Studies (DTS). In: GAMBIER, Y.; VAN DOORSLAER, L. (Ed.). Handbook of Translation Studies. Amsterdam; Philadelphia: John Benjamins, 2010. v. 1, p. 94-104.

TOURY, G. Descriptive Translation Studies and beyond. Amsterdam; Philadelphia: John Benjamins, 1995.

Recebido em agosto de 2017. Aprovado em setembro de 2017. 